\title{
Ice dams and backwaters as hydrological risk phenomena - case study: the Bistrita River, upstream of the Izvorul Muntelui Lake (Romania)
}

\author{
G. Romanescu \& O. Bounegru \\ "Alexandru Ioan Cuza" University of Iasi, Romania
}

\begin{abstract}
During the last 20 years, Romanian territory witnessed a recurrence of high-risk hydrologic phenomena. From this point of view, the floods and droughts are particularly noteworthy. Most of the rivers registered historic record levels, while droughts appear even in the mountainous hydrographic networks. Despite the fact that the frequency of rainfall increased during the same time-span, droughts are increasingly present since most of the precipitations are torrential in nature. It is precisely these precipitations of a torrential character that generate flood phenomena. Because Romania harbours a significant number of dams, especially in the mountainous sector, an increase in the number of backwater flooding is noticed. The only phenomenon which manifests itself with some regularity is to be found upstream of the Izvorul Muntelui Lake, on the valley of the River. Various natural and, particularly, anthropic causes favour the formation of ice-dams and Bistrita the flooding of the settlements upstream of the tail of the Izvorul Muntelui Lake. In most cases, the flooding was caused by backwater phenomenon $(1-3 \mathrm{~m})$. The overspills are due to ice-dams or the congestion of ice-floes along the course of the Bistrita. The building of houses on the minor bed, and the presence of bridges with the substructure embedded in the mid-channel, have favoured the generation of some of the most spectacular ice-dam ever formed on the river courses of the Carpathians. During winter, a significant contribution to the much-increased discharge levels of the Bistrita River is made by föhn phenomenon present in the upper sector of the river (the Vatra Dornei Depression). Unfortunately, during the last few years, the phenomenon occurs almost yearly, and the damage inflicted is considerable. The
\end{abstract}


floods caused by the backwater behind the ice-dams are unique in Romanian territory. The maximum thickness of the ice-dams can reach $6 \mathrm{~m}$. Keywords: backwater, ice dam, hydrological risk, Romania, water management.

\section{Introduction}

The dedicated hydrological and climatological literature mentions the onset of the desertification phenomenon in the eastern part of Romania. The last years have witnessed higher average precipitations falling on Romanian territory. Extreme phenomena, such as draughts and floods, are increasingly present, while the precipitations are mostly of a torrential character. The hydrological risk phenomena are primarily due to the massive deforestation taking place in the mountainous sectors [1].

During the last 20 years, most of the major rivers from the eastern part of Romania - the Prut, Siret, Suceava, Trotus, Tazlau, etc. - have witnessed historically-high discharge levels, and the total damage is significant [2-4]. Meanwhile, the droughts, particularly the summer ones, are among the most acute ever recorded in Romanian history $(2006,2011)$. The available national and international literature on hydrological risk phenomena is very consistent [5-14].

Most of the floods caused by collapsing ice dams occur in the cold (sub-polar and polar) regions of the globe. Those that occur in contexts similar to those of the mountainous regions of Romania are extremely rare. In most cases, they are due to the extensive modification of the environment by human activity. Winter water surges are hydrological risk phenomena which are very rarely observed at medium latitudes and low elevations. They are somewhat frequent in the case of the Mediterranean climate.

Most floods caused by backwater are due to various causes: bridges with under-dimensioned apertures or bridges with piers built on the stream bed; ice jams blocking the watercourses; powerful tides associated with strong winds coming from the sea; the existence of seiches; the presence of dams or dykes which force the excess water upstream in the critical sectors.

The existing Romanian scholarly literature is relatively brief in describing backwater phenomena. The first observation of a backwater flood was made by Dimitrie Cantemir [13] in his famous Descriptio antiqui et hodierni status Moldaviae, where he records the gushing of the Danube's waters into the mouths of the Prut River. The most recent Romanian studies mention the backwaters caused by the existence of hydroelectric dams [4], by the ice jams on the rivers from mountainous areas [10], or under marine influence at the mouths of the Danube [11].

The main scope of the present study is to highlight the causes that lead to the formation of ice dams and backwaters, to bring attention to the damage inflicted by the most important winter hydrological risk phenomena, to propose concrete measures for preventing the formation of ice dam and, implicitly, the recurrence of floods. 


\section{Regional setting}

The Bistrita River runs on the central-eastern part of the Eastern Carpathians, and it is the most important right-bank tributary of the Siret River (Figure 1). The Bistrita rises from under the ridge that connects the Gargalau peak with the Cimpoiesul peak from the Rodnei Mountains. The main stream is located at the end facing the Gargalau, at an elevation of $1835 \mathrm{~m}$. In reality, the Bistricioara is the source of the Bistrita, with its exact coordinates at 47 $34^{\prime} 27^{\prime \prime}$ northern latitude and $24^{\circ} 48^{\prime} 9^{\prime \prime}$ eastern longitude. The strongest stream is at the western edge of the Gargalaului, at $1835 \mathrm{~m}$ in elevation, while the highest is to the west of it, at $1850 \mathrm{~m} \mathrm{[4].}$

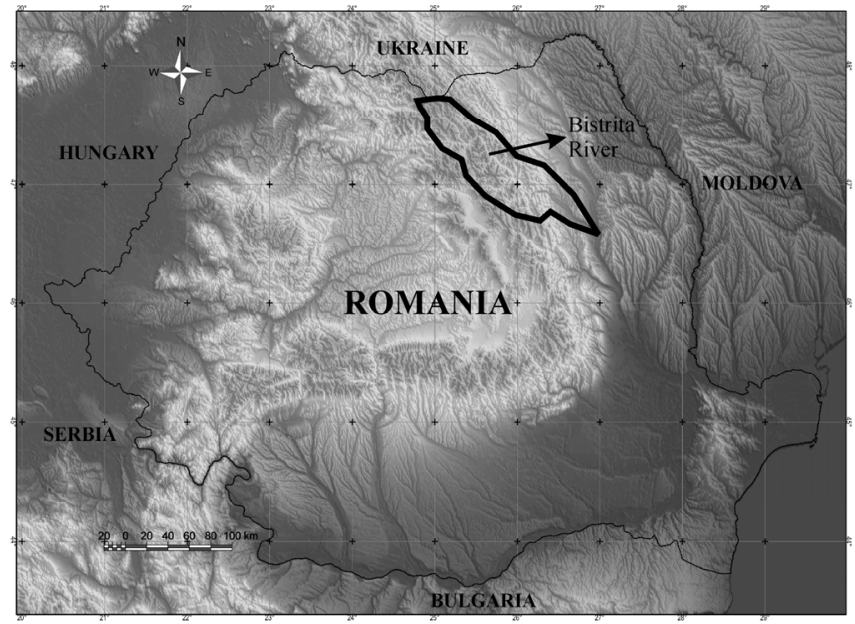

Figure 1: The geographic position of the Bistrita River drainage basin.

It flows into the Siret River, upstream of the city of Bacau, at $46^{\circ} 29^{\prime}$ northern latitude and $26^{\circ} 57^{\prime} 52^{\prime \prime}$ eastern longitude. The downstream receiver is the Galbeni reservoir. The elevation of the downstream base level is of $134 \mathrm{~m}[7,11]$.

The Bistrita River has a length of $283 \mathrm{~km}$ and collects its waters from an area of $7039 \mathrm{~km}^{2}$. The average slope is $5 \%$, the sinuosity index is 1.40 , the average elevation is $919 \mathrm{~m}$, and the forested area inside the drainage basin totals 424,301 ha. The river passes through three counties: Suceava, Neamt and Bacau.

The Bistrita has the greatest hydro-energetic potential of all the rivers from the Eastern Carpathians. For this reason, it witnessed intensive hydrotechnical works: along the lower half of its course, no less than 14 hydroelectric power plants were built since the turn of the last century. The most important storage reservoir is the Izvorul Muntelui Lake, built in 1960. This artificial lake is also largely responsible for favouring the development of the ice dams from the Poiana Largului-Farcasa sector. 


\section{Materials and methods}

Since the catchment basin of the Bistrita River is large and its morphology diverse, obtaining the necessary data required a laborious work of collecting from various institutions and conducting field measurements in several representative locations.

Statistical data were obtained from the Department of Water Management from the Siret River, Bacau, from the Moldavian Meteorological Centre, Bacau, and from the Romanian Waters National Administration, Bucharest. The data was processed in the Laboratory of Geo-Archeology within the Faculty of Geography and Geology from the "Alexandru Ioan Cuza" University of Iasi.

Real satellite images were taken from the Remote Sensing and GIS Laboratory of the National Administration of Meteorology and Hydrology, and partially processed or interpreted at the Remote Sensing and GIS Laboratory and the Geo-Archeology Laboratory within the Faculty of Geography and Geology from the "Alexandru Ioan Cuza" University of Iasi. Most of the satellite images that were already processed were taken from the Romanian Space Agency (ROSA) which made them publicly available on the Internet through the PNCD12 Project (http://sigur.rosa.ro).

Land observations and measurements were taken between 2002 and 2003, and in 2009. The major route had flooded river beds Bistrita and Petru Voda. The levels were monitored daily at three stations and topographical measurements were made upstream and downstream from it. All the data analyzed is taken from two meteorological stations (Vatra Dornei and Bicaz) and from three rainfall stations (Carlibaba, Dorna Candreni and Dorna Arini).

The data submitted by the communal and municipal authorities, and the data collected on-site, from local inhabitants or through individual observation, were processed in order to assess the damage at a local and regional level. The data regarding the damage to the infrastructure, especially to roads and railways, was taken from the relevant ministries.

\section{Results and discussion}

A flash-flood is a sudden and powerful increase of a flowing or static water body's levels. During flash floods, the water overflows its banks, gushing out of the minor bed, and invades the floodplain. Simple flash-floods can be caused by the collapse of a natural dam (an ice dam or a debris dam), heavy rains, snow melting etc. Complex flash floods interfere over the same hydrographical basin and are specific to rivers which flow over diverse geographical regions. The water body which suddenly swells the river and moves downstream is called a flash flood wave. The point of the wave were the elevation (wave height) is greatest is called a crest or peak. Flash floods can be categorised according to size and frequency into: annual flash floods (regular), decennial flash floods (large), exceptional flash floods (once every 100-1000 years; also called catastrophic floods because of their remarkable force and the enormous damage 
they cause). Retention lakes and dams lessen the impact of the flash floods by trimming their crest and forcing a laminar flow of the water.

In the case of the Bistrita River, of particular interest are the winter flash floods which are not caused by excessive precipitations, but by the factors specific to certain climatic conditions typical of this mountainous riverine sector, as well as by the human-induced changes in the landscape of the Bistrita Valley.

For a better understanding of the processes behind the formation of ice dams and the generation of winter flash floods, we must carefully study the transversal sections of the Bistrita Valley co-jointly with the longitudinal profile of the river. The hydrotechnical facilities, as well as the buildings erected without a preliminary impact study (especially those raised after 1990), should also be considered for our undertaking. Thus, most of the new residences were built on the major bed of the Bistrita, obstructing and practically reducing the real section. Alongside the houses and their outbuildings, small-scale industrial facilities (sawmills) also appeared on the river's major bed. Nonetheless, the most important factor which favours the formation of ice dams is the presence of the Izvorul Muntelui reservoir lake. Its presence facilitated the deposition of alluvial materials at the entrance of the river into the reservoir, and a major decrease of the slope (Figure 2).

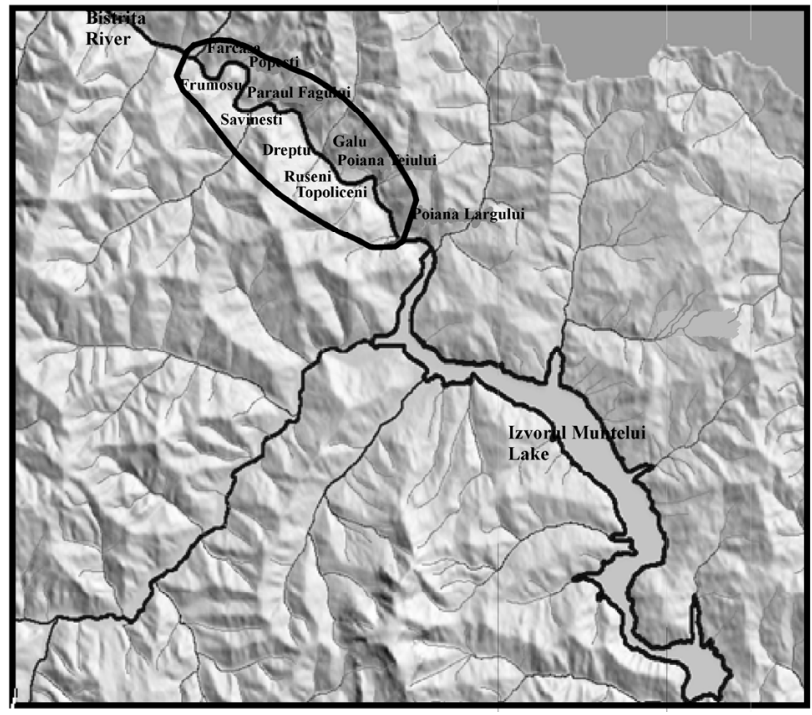

Figure 2: The morphology of the Bistrita Valley and the sector affected by the development of the ice dam.

The Bistrita Valley, upstream of the Izvorul Muntelui Lake, is characterised by a series of narrow sectors which alternate with relatively shallow depression basins, which favoured the establishment of human settlements. Unfortunately, countless numbers of bridges were built to ensure vehicle or pedestrian access in the villages. Because of the decreased span size between the piers of the bridges, 
the normal release of water out of the ice dams is impeded. The situation is exacerbated by the build-up of logs, branches silt and other debris transported by the previous floods. Most of the tree trunks are due to wood poaching: the heavy logs and thin branches are stored by the poachers on the mountainside, and during torrential rainfall the material is quickly transported into the river bed where they get stuck under the bridges, particularly when the latter have a central pile embedded in the mid-channel. In these cases, an increase of the apertures of between the piles, and even an anthropic sinking of certain sectors of the riverbed, is required to increase the speed of the flowing water, particularly during the winter.

Most of the high-risk hydro-meteorological phenomena occurred, during the last years, between January and April. In the Bistrita Valley, human settlements, defence works, bridges and catwalks, roads, small-scale lumber mills, agricultural lands, etc. have been severely affected.

The causes that can trigger the winter phenomena on the Bistrita river can be grouped into two categories: natural and anthropic.

The natural causes can be synthesised thus: Sustained very-low atmospheric temperatures $\left(<-10^{\circ} \mathrm{C}\right.$ or even $\left.-7^{\circ} \mathrm{C}\right)$ for a long time period, which lead to the formation of compact ice formations; Large diurnal temperature fluctuations for short time periods; The successive presence, in the longitudinal profile, of sectors with different slopes, the presence of meanders, and of sectors with narrow widths, including those of the minor bed; The very reduced spans of the Bistrita couloir (the major bed with widths between 300 and $1500 \mathrm{~m}$, and with the minor bed between 50 and $80 \mathrm{~m}$ in width); The ingression of air masses with high temperatures, as a consequence of the föhn phenomenon, from the Tihuta Pass towards the Dornelor Depression (the upper basin). The föhn phenomenon causes high temperatures in the upstream sector, which lead to the dislodging of the ice build-up, even during the winter, and its downstream transport and accretion as ice dams. Consequently, the levels of the water rises and the backwater wave causes flooding behind the jams.

The anthropic causes can be grouped thus: The presence of constructions: bridges, houses and outbuildings, fencings, saw mills, etc.; The presence of finalised or non-finalised hydrotechnical works (straight on the river bed): the Topoliceni and Paraul Pantei hydro-electric facilities; The existence of the Izvorul Muntelui reservoir, with direct effects on the hydro-meteorological phenomena due to the alteration of the local base level (the aggradation and avulsion phenomenon through the fan delta depositional feature).

The ice dam is formed in an area reaching $25-30 \mathrm{~km}$ in length, up until the settlement of Farcasa (Figure 3). Ever since the Izvorul Muntelui dam was built (it was inaugurated in 1960), this phenomenon occurs regularly, once every 3-5 years. The artificial lake has a length of $33 \mathrm{~km}$ and stores a volume of 1.23 billion cubic meters. In 2003, the Topoliceni hydro-energetic facility was brought into service. It is situated upstream of the Izvorul Muntelui reservoir, and its lake has a length of $3.6 \mathrm{~km}$. After this second dam on build on the Bistrita, the problem became more acute: ice dams started to form on a yearly basis, and the maximum thickness of the ice sheet can reach 6-7 m. 


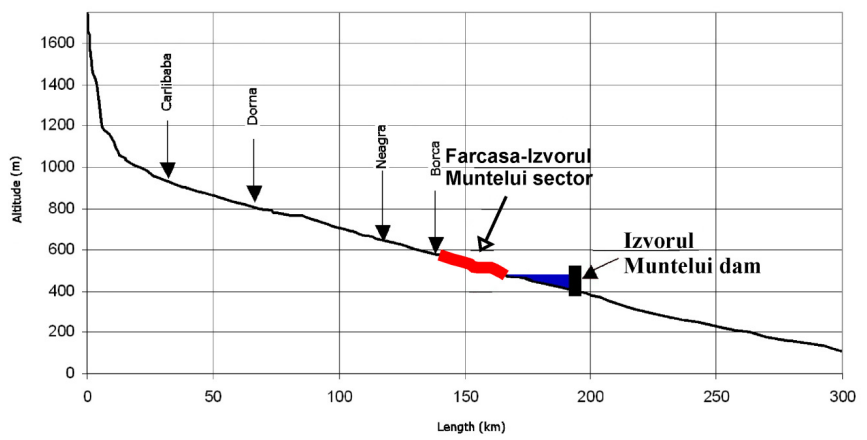

Figure 3: The longitudinal profile of the Bistrita Valley and the outset alignment in the Farcasa-Izvorul Muntelui sector.

In most case, the first occurrences (from December and January) of ice dam happen upstream of the village of Popesti. At the beginning of winter, the thermal inversion phenomenon has not yet manifested, and the moderating character of the Izvorul Muntelui Lake is only felt in the immediate vicinity of it. The entire sector between Farcasa and Poiana Largului is engulfed by the ice dam between February and March, when thermal inversion phenomena take hold of the entire sector between Farcasa and Izvorul Muntelui (Figure 4).

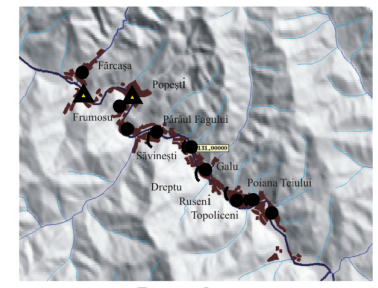

December

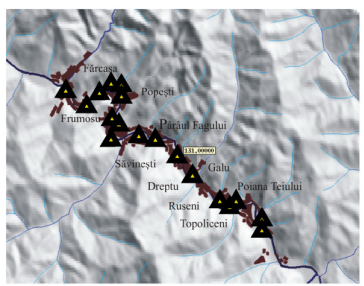

February

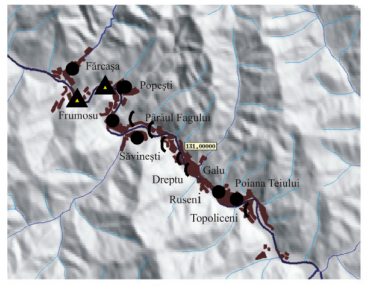

January

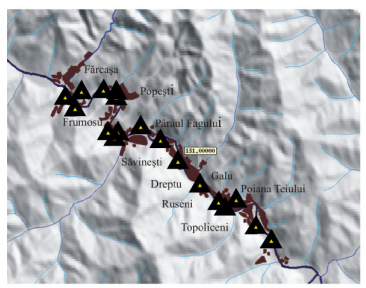

March

Figure 4: The distribution of the ice dams during the winter of 1995-1996. 
During severe winters, with temperatures under $-7^{\circ} \mathrm{C}$, an ice dam can be in place for the entire time span between December and March (Figure 5). In such cases, the thermal inversions occur as early as December.

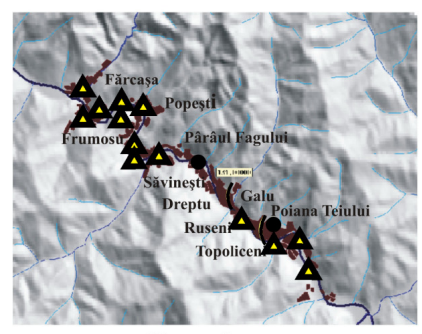

December

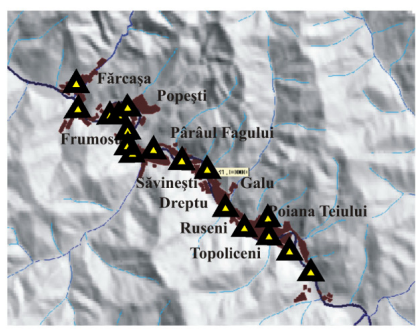

February

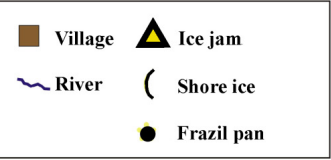

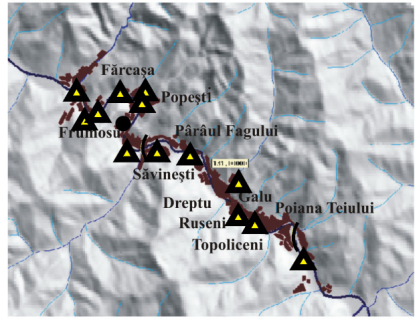

January

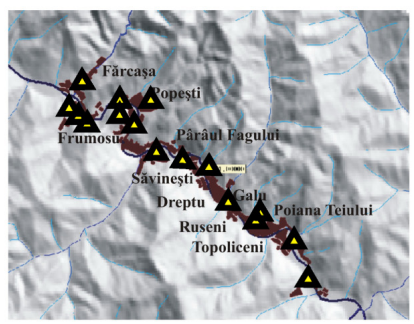

March

Figure 5: The distribution of ice dams during the winter of 2002-2003.

We should highlight the fact that the ice dams did not start to form immediately after the reservoir appeared in the path of the Bistrita, but only after the silt carried by the river started to accumulate at the tail of the lake. After the delta-fan alluvial cone took shape, and the inclination of the slope was considerably reduced, the first oversized ice dams started to appear (in 19751976, 1981-1982, 1998-1999 and 1999-2000). Since the Topoloveni dam was built, the frequency of ice dams increased and, implicitly, so did the frequency of the winter backwaters (in 2000-2001, 2001-2002; 2002-2003, 2003-2004, 2004-2005, 2005-2006, 2006-2007, 2008-2009, 2009-2010, 2010-2011). Consequently, the phenomenon acquired a yearly frequency and it becoming increasingly dangerous.

The most frequent flash floods on Romanian territory occur in spring and at the beginning of summer (April, May, June). Those from during winter are rare and only occur in South-Eastern Romania where some influences of the SubMediterranean climate are observed. The mountainous winter flash floods, from the upper sectors of the Bistrita, are unaffected by the general climate of the area, but by the local climate influences (föhn in the north, and thermal inversion in 
the south). The föhn is favoured by the intrusion of air masses from the west, through the Tihuta pass, and their descent into the Dornelor Depression. The thermal inversions are favoured by the presence of the depression basins along the Bistrita Valley. In this case, the cold air is dispersed with difficulty, since it stagnates for long periods of time on the bottom of the valley.

In the upper sector of the Bistrita, in the Dornelor Depression (to the north of Farcasa), the dominant winds of the winter months have the highest frequency on the West-East direction (Figure 6). As they descend, they produce the föhn which, in its turn, causes the rapid melting of the snow. This high volume of water spills over the ice from downstream.
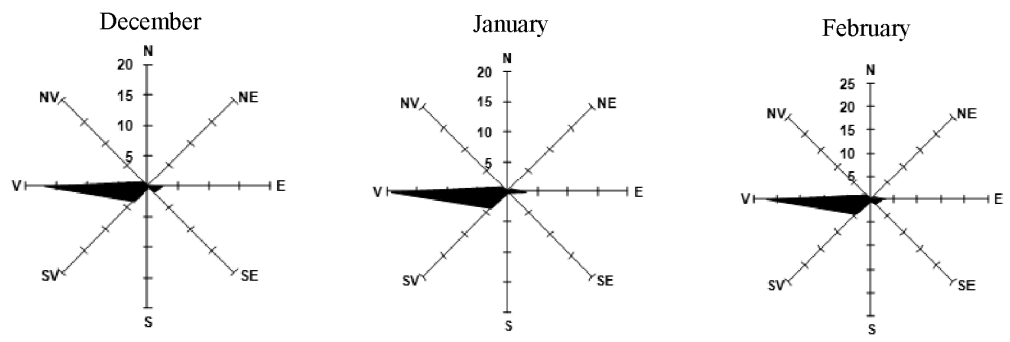

Figure 6: The frequency of the winds according to their directions, during the months of December, January and February 2002 (Vatra Dornei weather station).

The average thickness of the ice dams (or ice jams) is $2-3 \mathrm{~m}$, but they can reach a maximum of 6-7 m. During winters, a peculiar feature of the river is that there is not liquid water present in the minor bed. The waters flow only above the surface of the ice, and in most cases they follow a downstream-upstream path for the $25-30 \mathrm{~km}$ long sector from the tail of the Izvorul Muntelui Lake.

The flash-flood which affected the Bistrita River between the 26th of February and the 30th of March, 2002, had the general features similar to the majority of flood phenomena from the Bistrita Valley.

The climatological and hydrological measurements were conducted at the Carlibaba and Dorna Arini (for the Bistrita), and at Dorna Candreni (for the Dorna River, a tributary of the Bistrita). The inflow of water from the Dorna occurred simultaneously with the flash flood on the Bistrita; therefore, the volume of the discharge downstream of the confluence increased considerably. At the confluence, the discharge of the Dorna was much larger than that of the upstream-sector Bistrita. To highlight the role played by the winter 'foehnisation' in the upper sector, several hydrograph charts from the Vatra Dornei-Farcasa sector are herein presented (Figures 7 and 8).

Alongside 'foehnisation', another determining factor is the change of the slope due to the delta-fan alluvial cone formed on the Bistrita at the tail of the Izvorul Muntelui Lake. The alluvial cone caused the aggradation of the flow channel and the avulsion of the river bed. 

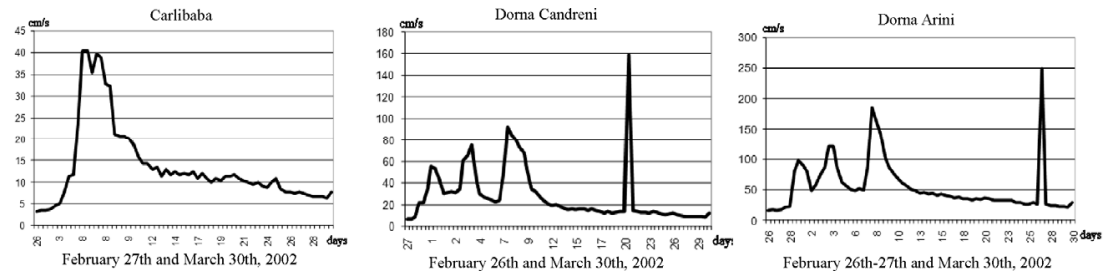

Figure 7: Hydrograph of the flash flood discharge of the Bistrita River at the Carlibaba, Dorna Candreni and Dorna Arini hydrographic stations, between February 26th and March 30th, 2002.

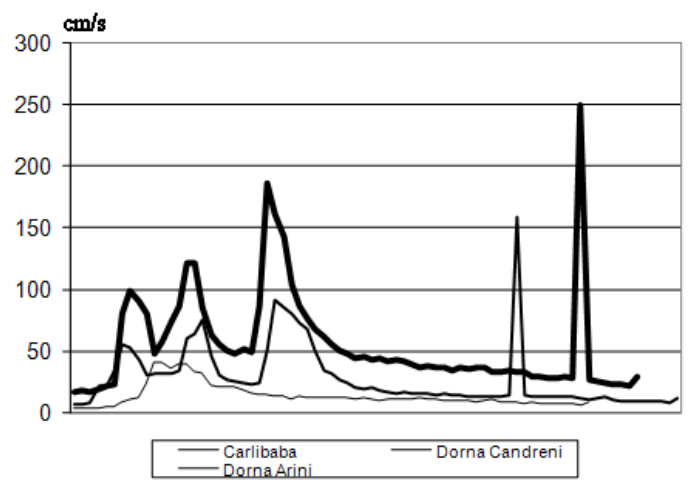

Figure 8: The comparative hydrographs of the flash flood discharges for the Bistrita and Dorna rivers at the Carlibaba, Dorna Candreni and Dorna Arini hydrographic stations, between February 26th-27th and march 30th, 2002.

The alluvial deposits from upstream of the reservoir lake are called "regressive accumulation" in Russian literature, and "progressive aggradation" in American works. This geomorphological feature is the direct result of the forming of fan-deltas and the migration of backwater curve on the river bed, that is to say, the effect of the new local base level [10-11].

During the winter of 2003, a massive accretion of ice-floes created a 7-meterthick ice plug on the Bistrita. If regular ice dams have an average life of 90-95 days, the one from the winter of 2003 was in good condition for 106 days. The backwater had a maximum intensity between December 31st, 2002, and January 2nd, 2003, during which it raised the water level by $3 \mathrm{~m}$. The greatest material damage occurred during this time; the settlement of Valea Muntelui was hit particularly hard, with 3 people dead and 98 houses damaged. This flood was caused by a warming that took place for a relatively short time span, and during which the temperatures reached $3-5^{\circ} \mathrm{C}$.

To prevent further destructive flash floods, particularly upstream of the tail of the Izvorul Muntelui Lake, the following measures must be put into effect: the proper maintenance of the river beds; the sinking of the minor bed as to increase 
the discharge speed; the foresting of the mountain versants, and the alleviation of soil erosion; the correction of the torrential flow paths through systematisation works; the continuation of the work on the hydro-energetic development of the Bistrita river, in the Borca-Poiana Teiului sector; the regularisation of the river beds, especially in the meandered sectors of the Bistrita, Dorna, and Neagra rivers; the re-calibration of several bridge apertures, and the automatic monitoring of the integrated system.

\section{Conclusions}

In comparison with other hydrographical systems from the Eastern Carpathians, the Bistrita River also witnesses winter flash floods, due to the combination of several factors: the air 'foehnisation' in the upper sector and the instalment of maximum centres (thermal inversions) in the basins from the lower sectors, which favour the stagnation of the ice dam for long periods of time. The anthropic factor also facilitated the yearly manifestation of the phenomenon.

Although the backwater phenomenon is relatively well known in the Romanian scholarly work, the peculiar features of the phenomenon as it unfolds on the Bistrita River during winters, when massive ice plugs form on its course, make it distinctive and noteworthy. The backwater wave can reach $3 \mathrm{~m}$ in height, even when the ice sheet is already 6-7 m thick. To break the ice dams or the ice bridges, the authorities habitually resort to using high-powered explosives (dynamite).

The area affected by these floods is quite large, and the material losses are often significant, but these are rightfully overshadowed by the, albeit occasional, loss of human life. The automatic monitoring of the flash floods and the adequate forewarning of the population is imperative for the future.

\section{Acknowledgements}

Our thanks go to the Geo-archaeology Laboratory of the ARHEOINVEST Research Platform in the Field of Archaeology, within the Faculty of Geography and Geology from the "Alexandru Ioan Cuza" University of Iasi, which provided the instruments and carried out the processing of the data.

The Ministry of Education and Research paid for the measurements and the publication through CNCS grant no. 0857, for the period 2011-2014, with Professor Octavian Bounegru, Ph. D., as a grant director.

\section{References}

[1] Romanescu, G., Siret river basin planning (Romania) and the role of wetlands in diminishing the floods. WIT Transaction on Ecology and the Environment 125, pp. 439-453, 2009. DOI: 10.2495/WRM090391. 
[2] Romanescu, G. and Nistor, I., The effect of the July 2005 catastrophic inundations in the Siret River's Lower Watershed, Romania. Natural Hazards 57(2), pp. 345-368, 2011. DOI: 10.1007/s11069-010-9617-3.

[3] Romanescu, G., Jora, I. and Stoleriu, C., The most important high floods in Vaslui river basin - causes and consequences. Carpathian Journal of Earth and Environmental Sciences 6(1), pp. 119-132, 2001a.

[4] Romanescu, G., Stoleriu, C. and Romanescu, A.M., Water reservoirs and the risk of accidental flood occurrence. Case study: Stanca-Costesti reservoir and the historical floods of the Prut river in the period JulyAugust 2008, Romania. Hydrological Processes 25, pp. 2056-2070, 2011 b. DOI: 10.1002/hyp.7957.

[5] Kuhlicke, C., The dynamics of vulnerability: some preliminary thoughts about the occurrence of radical surprises and a case study on the 2002 flood (Germany). Natural Hazards 55(3), pp. 671-688, 2010.

[6] Beltaos, S., The role of waves in ice-jam flooding of the Peace-Athabasca Delta. Hydrological Processes 21(19), pp. 2548-2559, 2007.

[7] Ciaglic, V., Evolutia fenomenului de inghet pe raul Bistrita in iarna 19631964. Hidrotehnica 10(2), pp. 92-101, 1965.

[8] Kowalczyk, T. and Hicks, F., Observations of dynamic ice jam release waves on the Athabasca River near Fort McMurray. Canadian Journal of Civil Engineering 34, pp. 473-484, 2003.

[9] Prowse, T.D. and Beltaos, S., Climatic control of river-ice hydrology: a review. Hydrological Processes 16, pp. 805-822, 2002.

[10] Radoane, M., Ciaglic, V. and Radoane, N., Hydropower impact on the ice jam formation on the upper Bistrita River, Romania. Cold Regions Science and Technology 60, pp. 193-204, 2010.

[11] Romanescu, G., Riscul inundatiilor in amonte de lacul Izvorul Muntelui si efectul imediat asupra trasaturilor geomorfologice ale albiei. Riscuri si catastrofe 4, pp. 117-124, 2005.

[12] Shi, J., Zhang, Y. and Zhang, F., Analysis on Backwater Calculation of Ice Jam During Ice-flood Period. Advances in Materials Research 243-249, pp. 4458-4461, 2011.

[13] Cantemir, D., Descriptio Moldaviae, Berlin, 1716.

[14] Stefanache, M., Cercetari privind evolutia unor fenomene hidrologice periculoase, PhD Thesis, Universitatea Gh.Asachi, Iasi, 2007. 